\title{
A structure of $\mathrm{CdS} / \mathrm{Cu}_{\mathrm{x}} \mathrm{S}$ quantum dots sensitized solar cells
}

\author{
Ting Shen, ${ }^{1}$ Lu Bian, ${ }^{1}$ Bo Li, ${ }^{1}$ Kaibo Zheng, ${ }^{2}$ Tönu Pullerits, ${ }^{2}$ and Jianjun Tian ${ }^{1, a)}$ \\ ${ }^{1}$ Institute of Advanced Materials and Technology, University of Science and Technology Beijing, \\ Beijing 100083, China \\ ${ }^{2}$ Department of Chemical Physics, Lund University, Box 124, 22100 Lund, Sweden
}

(Received 4 March 2016; accepted 11 May 2016; published online 24 May 2016)

\begin{abstract}
This work introduces a type of $\mathrm{CdS} / \mathrm{Cu}_{\mathrm{x}} \mathrm{S}$ quantum dots (QDs) as sensitizers in quantum dot sensitized solar cells by in-situ cationic exchange reaction method where CdS photoanode is directly immersed in $\mathrm{CuCl}_{2}$ methanol solution to replace $\mathrm{Cd}^{2+}$ by $\mathrm{Cu}^{2+}$. The p-type $\mathrm{Cu}_{\mathrm{x}} \mathrm{S}$ layer on the surface of the CdS QDs can be considered as hole transport material, which not only enhances the light harvesting of photoanode but also boosts the charge separation after photo-excitation. Therefore, both the electron collection efficiency and power conversion efficiency of the solar cell are improved from $80 \%$ to $92 \%$ and from $1.21 \%$ to $2.78 \%$, respectively. Published by AIP Publishing. [http://dx.doi.org/10.1063/1.4952435]
\end{abstract}

Various types of quantum dot solar cells (QDSC) have been intensively studied ever since Vogel and Weller ${ }^{1}$ reported $\mathrm{PbS}$ and $\mathrm{CdS}$ QDSCs. The advantages of quantum dots (QDs) as light harvesters in solar cells include the sizetunable band-gaps, ${ }^{2}$ high extinction coefficient, ${ }^{3}$ and possible hot carrier injection. ${ }^{4}$ In particular, the multiple exciton generation (MEG) of QDs ${ }^{5}$ can suppress Schockley-Queisser limit $^{6,7}$ and rise the theoretical maximum power conversion efficiency (PCE) from $31 \%$ up to $44 \%$. However, the state of art chalcogenide QDs based QDSCs (e.g., $\mathrm{CdSe},{ }^{8} \mathrm{CdS},{ }^{9}$ $\mathrm{PbS},{ }^{10} \mathrm{CdSe} / \mathrm{CdS},{ }^{11} \mathrm{CuInS}_{2},{ }^{12} \mathrm{CuInSe},{ }^{13}$ and $\mathrm{CdSe}_{1-\mathrm{x}} \mathrm{Te}_{\mathrm{x}}{ }^{14}$ QDs) shows the highest PCE up to $9.48 \%$ (Ref. 15) still significantly lower than that of conventional Si solar cells and thin film solar cells. To date, many efforts have been made to optimize the configuration of the QDSC towards expected PCE, such as the adapted polysulfide electrolyte, ${ }^{16}$ new type counter electrode, ${ }^{17}$ different morphology of mesoporous photoanode films, ${ }^{18}$ and QDs engineering by absorption extension, element doping, and surface modification. ${ }^{19-21}$

In nanometer-sized QDs, the surface to interior atom ratio is high. The surface atoms have lower coordination number than the corresponding volume atoms leading to high probability that they act as the electrons or holes traps. ${ }^{22}$ In addition to such surface defects, the surface facets and chemistry of QDs may also affect the conformal coating and adhesion of QDs. Many efforts have been focused on the surface modification of QDs to enhance the efficiency of QDSCs. CdSe QDs can be modified by coating them with $\mathrm{ZnS}$ shell for improving the fluorescence quantum yield of $\mathrm{QDs}^{23}$ and performance of QDSCs. ${ }^{24}$ For QDSCs, ZnS coating layer can overcome the recombination losses leading to the higher photocurrents. ${ }^{25}$ Recently, Pan et al. ${ }^{26}$ achieved effective surface passivation of the ternary $\mathrm{CuInS}_{2}$ (CIS) QDs using ZnS to form core/shell CIS/ZnS (CIS-Z) QDs. The QDSCs based on CIS-Z QDs show a very high PCE of $7.04 \%$ and a certified efficiency of $6.66 \%$. Zhao et al. ${ }^{27}$ boosted the efficiency of QDSCs beyond $8 \%$ by introducing a novel sequential inorganic $\mathrm{ZnS} / \mathrm{SiO}_{2}$ double layer to reduce

${ }^{\text {a)} E-m a i l: ~ t i a n j i a n j u n @ m a t e r . u s t b . e d u . c n ~}$ recombination processes. Zhang et al. ${ }^{28}$ increased the stability and prolonged hot carrier lifetime in QDSCs using the halide treatment. Clearly, the interface modification is recognized as an effective approach for improving the performance of QDSC.

Here, a p-type semiconductor interfacial layer of $\mathrm{Cu}_{\mathrm{x}} \mathrm{S}$ was deposited on the surface of CdS QDs layer using an in-situ cationic-exchange method as shown in Scheme 1. CdS QDs were first directly grown on the mesoporous $\mathrm{TiO}_{2}$ film using successive ionic layer absorption and reaction (SILAR) method. ${ }^{29}$ Thereafter, CdS photoanodes were immersed in $1.0 \mathrm{mM}$ copper chloride solution for $3 \mathrm{~s}$ and then rinsed with methanol and dried with air. The $\mathrm{Cd}^{2+}$ ions of $\mathrm{CdS}$ QDs were replaced by $\mathrm{Cu}^{2+}$ ions to form $\mathrm{Cu}_{\mathrm{x}} \mathrm{S}$ shell. (For the optimization of the device fabrication, see Figure S1 of supplementary material. ${ }^{30}$ ) The cationic exchange reaction takes place at the surface of CdS QDs. As a result, a portion of surface $\mathrm{Cd}$ atoms is replaced by $\mathrm{Cu}$ atoms. The energy-dispersive X-ray spectroscopy (EDX) was conducted to monitor the elemental compositions of the CdS and CdS/ $\mathrm{Cu}_{\mathrm{x}} \mathrm{S}$ QD sensitized $\mathrm{TiO}_{2}$ photoanodes (see Figure $\mathrm{S} 1$ of supplementary material ${ }^{30}$ ). The amount of the $\mathrm{Cu}$ element in the $\mathrm{CdS} / \mathrm{Cu}_{\mathrm{x}} \mathrm{S}$ sensitized photoanodes increases as copper precursor solution concentration increases. The amount of the $\mathrm{Cd}$ element in the $\mathrm{CdS} / \mathrm{Cu}_{\mathrm{x}} \mathrm{S}$ sensitized photoanodes films decreases accordingly. The X-ray diffraction patterns (XRD) of the $\mathrm{CdS}$ sensitized photoanodes with and without $\mathrm{Cu}_{\mathrm{x}} \mathrm{S}$ modification (see Figure S2 of supplementary material ${ }^{30}$ ) further confirm the presence of $\mathrm{Cu}_{\mathrm{x}} \mathrm{S}$ in photoanodes. Additional diffraction peaks at $2 \theta=27.6^{\circ}, 36.4^{\circ}, 41.3^{\circ}$, and $55.2^{\circ}$ assigned to copper sulphide are observed in $\mathrm{CdS} / \mathrm{Cu}_{\mathrm{x}} \mathrm{S}$ sensitized photoanode compared with the neat $\mathrm{CdS}$ photoanode. However, the peaks match neither $\mathrm{CuS}$ phase nor $\mathrm{Cu}_{2} \mathrm{~S}$ phase. Therefore, the reaction product is called $\mathrm{Cu}_{\mathrm{x}} \mathrm{S}$ in this work.

Scheme 1(b) illustrates the role of p-type semiconductor $\mathrm{Cu}_{\mathrm{x}} \mathrm{S}$ layer in the functioning of CdS QDSCs. Upon illumination of light, $\mathrm{CdS} / \mathrm{Cu}_{\mathrm{x}} \mathrm{S}$ QDs can absorb photon to excite electron-hole pairs. The hole transfer to electrolyte is mediated by the $\mathrm{Cu}_{\mathrm{x}} \mathrm{S}$ layer, while electron injection can only 
(a)
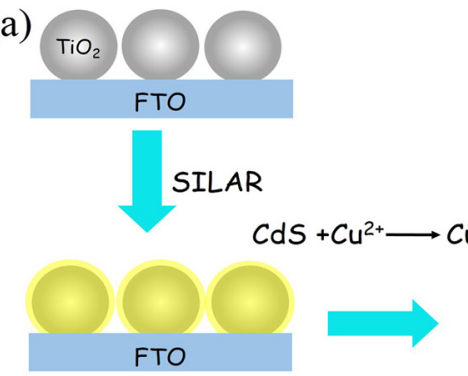

(c)

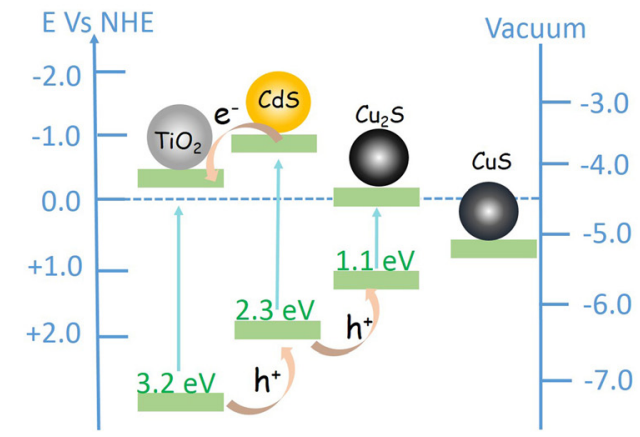

(b)
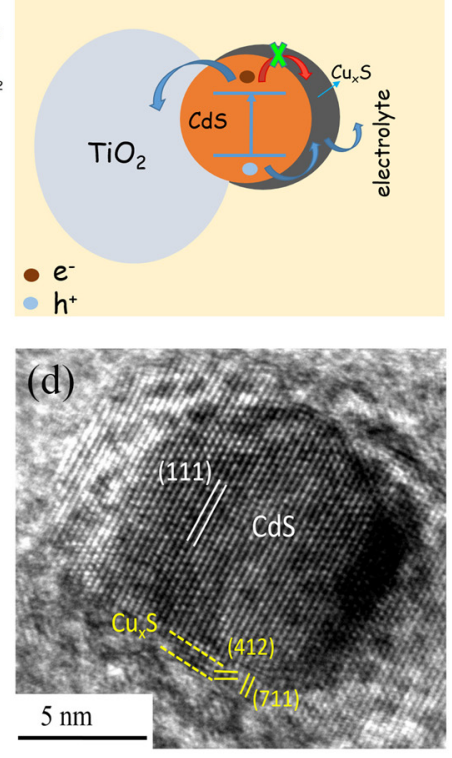

SCHEME 1. (a) Schematic illustration of in-situ cationic exchange from $\mathrm{CdS}$ to $\mathrm{Cu}_{\mathrm{x}} \mathrm{S}$ and (b) $\mathrm{Cu}_{\mathrm{x}} \mathrm{S}$ as a hole transport layer for charge separation from CdS QDs, (c) Energy band structure of $\mathrm{TiO}_{2} / \mathrm{CdS} / \mathrm{Cu}_{2} \mathrm{~S} / \mathrm{CuS},{ }^{31}$ and (d) TEM images of $\mathrm{TiO}_{2}$ films loaded with CdS/ $\mathrm{Cu}_{\mathrm{x}} \mathrm{S}$. proceed from CdS directly to $\mathrm{TiO}_{2}$. In this scenario, geminate recombination at the interface between QDs and electrolyte is expected to be blocked by the $\mathrm{Cu}_{\mathrm{x}} \mathrm{S}$ layer. Scheme 1 (c) shows the values of the conduction bands (CB) of $\mathrm{TiO}_{2} /$ $\mathrm{CdS} / \mathrm{Cu}_{2} \mathrm{~S} / \mathrm{CuS}$. The values of the valence bands (CB) for copper sulfide would be like that $\mathrm{Cu}_{2} \mathrm{~S}<\mathrm{Cu}_{\mathrm{x}} \mathrm{S}<\mathrm{CuS}$. Because of the suited band gap structure between $\mathrm{TiO}_{2} / \mathrm{CdS}$ and $\mathrm{Cu}_{\mathrm{x}} \mathrm{S}, \mathrm{Cu}_{\mathrm{x}} \mathrm{S}$ would be a good hole mediator. Under the operating conditions, electron-hole pairs are rapidly separated, and the holes are reduced by redox couples $\left(\mathrm{S}^{2-} / \mathrm{S}_{\mathrm{n}}{ }^{2-}\right)$ through $\mathrm{Cu}_{\mathrm{x}} \mathrm{S}$. The layer suppresses recombination of electrons with holes in the electrolyte. ${ }^{32}$ Scheme 1(d) displays the TEM image of the $\mathrm{TiO}_{2}$ films loaded with $\mathrm{CdS} / \mathrm{Cu}_{\mathrm{x}} \mathrm{S}$, showing the existence of $\mathrm{Cu}_{\mathrm{x}} \mathrm{S}$ on the surface of $\mathrm{CdS}$ that is
1-3 nm in thickness (the yellow dash lines). Combined with $\mathrm{XRD}$ analysis, the copper sulfide is similar to $\mathrm{Cu}_{1.96} \mathrm{~S}$. The $10 \mathrm{~nm}$-sized CdS QDs may be attributed to the fact that the small QDs became aggregated. In this work, UV-visible absorbance, photoluminescence (PL), electrochemical spectra, and photo-electric measurements were carried out to prove the effect of $\mathrm{Cu}_{\mathrm{x}} \mathrm{S}$ layer on the enhancement of charge separation and electron collection in QDSCs.

Absorption spectra of $\mathrm{CdS}$ and $\mathrm{CdS} / \mathrm{Cu}_{\mathrm{x}} \mathrm{S}$ sensitized $\mathrm{TiO}_{2}$ photoanodes are shown in Figure 1(a). The absorbance of $\mathrm{CdS} / \mathrm{Cu}_{\mathrm{x}} \mathrm{S}$ sensitized photoanode is much higher than that of the neat $\mathrm{CdS}$ indicating better capability of photon absorption. In addition, the absorption onset of photoanode is redshift by introducing $\mathrm{Cu}_{\mathrm{x}} \mathrm{S}$ layer on the surface of $\mathrm{CdS}$
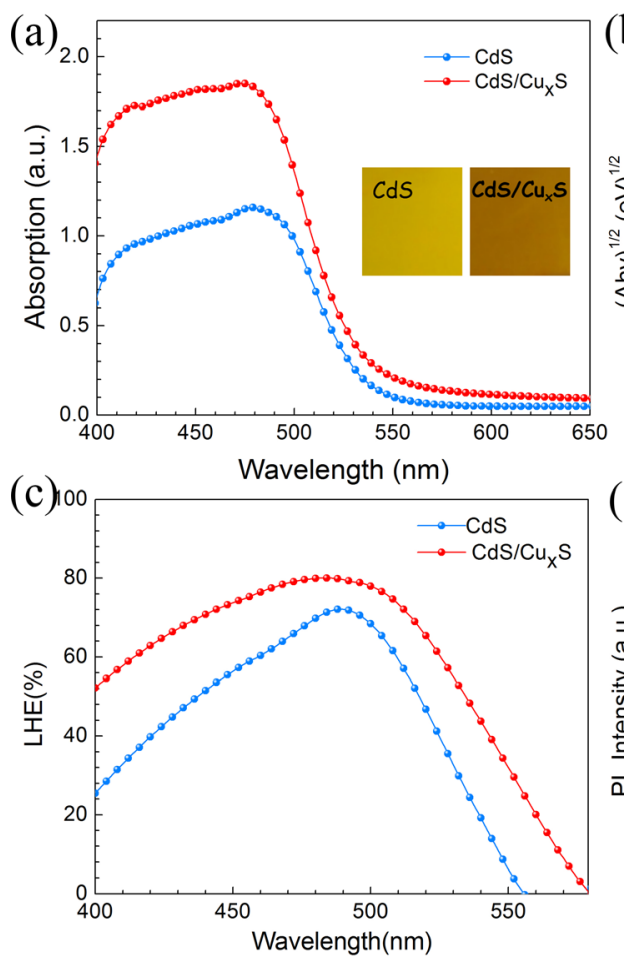

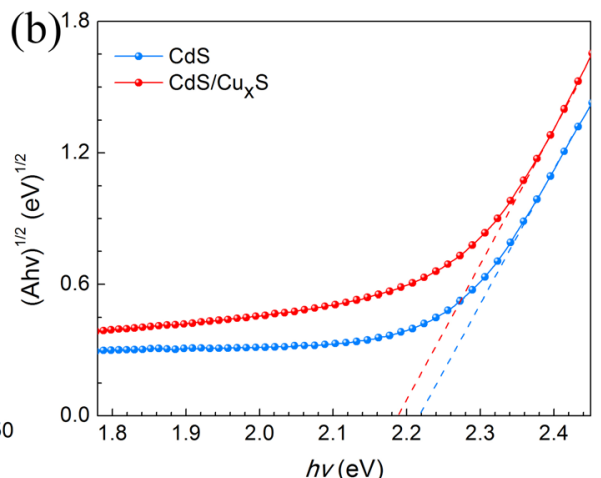

(d)

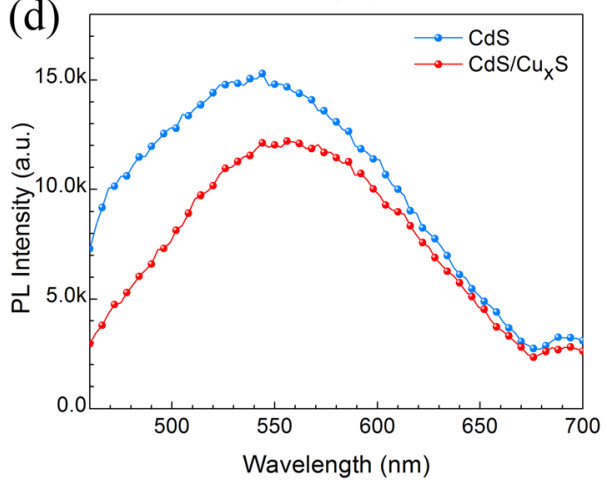

FIG. 1. (a) UV-vis absorption spectra, (inset shows the pictures of the CdS and $\mathrm{CdS} / \mathrm{Cu}_{\mathrm{x}} \mathrm{S}$ sensitized photoanodes), (b) Tauc-plots showing the optical band-gap of two samples, (c) light harvesting efficiency (LHE), and (d) Photoluminescence (PL) of the CdS sensitized photoanodes with and without $\mathrm{Cu}_{\mathrm{x}} \mathrm{S}$ surface layer (Excitation wavelength $325 \mathrm{~nm}$ ). 

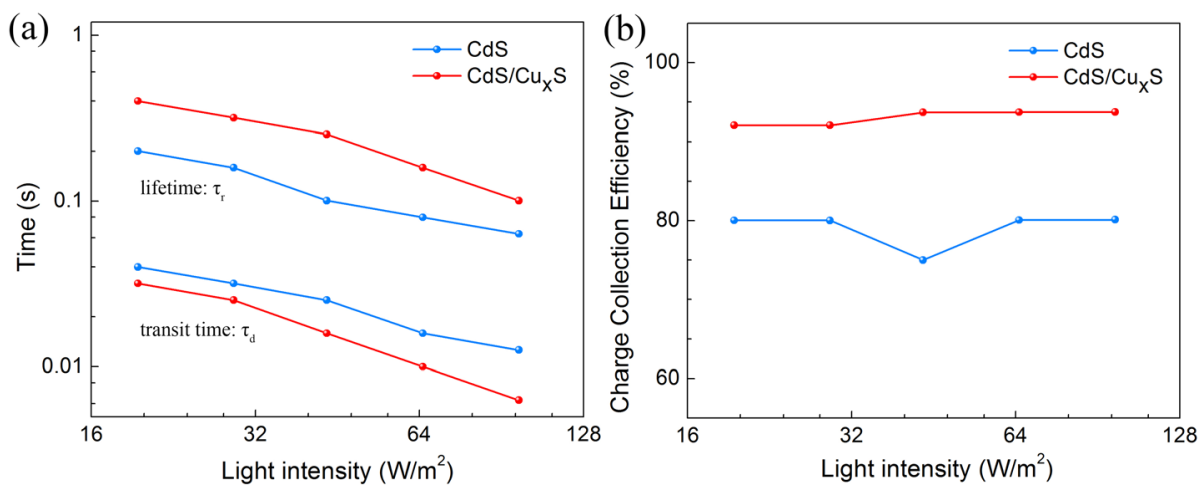

FIG. 2. (a) Electron transport time and lifetime and (b) effective charge collection efficiency of the CdS based QDSCs with and without $\mathrm{Cu}_{\mathrm{x}} \mathrm{S}$-surface layer.
QDs (see Figure 1(b)). $\mathrm{Cu}_{\mathrm{x}} \mathrm{S}$ is a narrow band-gap (1.2 eV) p-type semiconductor ${ }^{33}$ with a wide absorption range ( up to $850 \mathrm{~nm}$ ). The inset pictures display that the colour of $\mathrm{CdS} /$ $\mathrm{Cu}_{\mathrm{x}} \mathrm{S}$ sensitized photoanode is much darker than that of the CdS sensitized photoanode. We can also evaluate the optical band gap by the Tauc plots $\left((\mathrm{A} h v)^{1 / 2} \sim h v\right)$ of the absorption spectra as shown in Figure 1(b), where A is the absorbance, $h$ is the Plank's constant, and $v$ is the photon frequency. The $E_{g}$ (band-gap) can then be calculated ${ }^{34}$ to be $2.19 \mathrm{eV}$ for $\mathrm{CdS} / \mathrm{Cu}_{\mathrm{x}} \mathrm{S}$, which is lower than the $E_{g}(2.22 \mathrm{eV})$ of $\mathrm{CdS}$. Such narrowing of $E_{g}$ can be attributed to the lowering bandgap of $\mathrm{Cu}_{\mathrm{x}} \mathrm{S}(1.2 \mathrm{eV}),{ }^{33,35,36}$ compared with that of $\mathrm{CdS}$. The light harvesting efficiency (LHE) of $\mathrm{CdS} / \mathrm{Cu}_{\mathrm{x}} \mathrm{S}$ is also observed to be higher than QDSCs without $\mathrm{Cu}_{\mathrm{x}} \mathrm{S}$ layer as shown in Figure 1(c), which is consistent with the absorption spectra.

The role of $\mathrm{Cu}_{\mathrm{x}} \mathrm{S}$ layer in charge separation process could be studied by the steady-state photoluminescence (PL). As shown in Figure 1(d), PL intensity of the photoanode is reduced by adding $\mathrm{Cu}_{\mathrm{x}} \mathrm{S}$ layer on the surface of $\mathrm{CdS}$ QDs. One possible reason for such PL quenching would be the enhanced hole injection through $\mathrm{Cu}_{\mathrm{x}} \mathrm{S}$ layer which diminishes the radiative recombination between electrons and holes in the initial excited states. Other possibility such as interfacial trapping can be excluded here, as the decreased PL band width indicates the reduction of interfacial trapping state concentration if the $\mathrm{Cu}_{\mathrm{x}} \mathrm{S}$ layer is present in QDs. ${ }^{37,38}$ Moreover, the charge carrier dynamics and solar cell performance studies in the following part do confirm the improvement of the charge separation by $\mathrm{Cu}_{\mathrm{x}} \mathrm{S}$ layer coating in our system.

The electron transit and charge collection processes in the QDSC with and without $\mathrm{Cu}_{\mathrm{x}} \mathrm{S}$ modification were further characterized by intensity modulated photocurrent spectroscopy (IMPS) and intensity modulated photovoltage spectroscopy (IMVS) as shown in Figure 2(a). From the figure, we can compare the dependence of the time constants, the transit time $\left(\tau_{\mathrm{d}}\right)$ and electron lifetime $\left(\tau_{\mathrm{r}}\right)$, which can be measured by following equations: ${ }^{34}$

$$
\begin{aligned}
\tau_{\mathrm{d}} & =\frac{1}{2} \pi f_{\mathrm{d}}, \\
\tau_{\mathrm{r}} & =\frac{1}{2} \pi f_{\mathrm{r}},
\end{aligned}
$$

where $f_{\mathrm{d}}$ and $f_{\mathrm{r}}$ are the frequency of the minimum of the semicircle, i.e., the frequency of the lowest imaginary component in the IMPS and IMVS plots, respectively. As shown in Figure 2(a), the $\mathrm{CdS} / \mathrm{Cu}_{\mathrm{x}} \mathrm{S}$ based QDSC shows longer $\tau_{\mathrm{r}}$ and shorter $\tau_{\mathrm{d}}$ than those of CdS counterpart, which corresponds to longer electron life time and faster electron transit, respectively. These results manifest the more efficient charge separation and transit facilitated by $\mathrm{Cu}_{\mathrm{x}} \mathrm{S}$ layer, consistent with previous conclusion from PL measurement. The charge-collection efficiency $\left(\eta_{c c}\right)$ can also be calculated by $\tau_{\mathrm{d}}$ and $\tau_{\mathrm{r}}$ as ${ }^{39,40}$

$$
\eta_{c c}=1-\frac{\tau_{d}}{\tau_{r}} .
$$

The $\eta_{c c}$ of $\mathrm{CdS} / \mathrm{Cu}_{\mathrm{x}} \mathrm{S}$ solar cell is $92 \%$, which is higher than that of CdS solar cell (80\%).

The enhanced charge separation by $\mathrm{Cu}_{\mathrm{x}} \mathrm{S}$ modification does result in better solar cell performance as illustrated below. Figure 3(a) shows incident photon-to-current conversion efficiency (IPCE) spectra of the solar cells. The maximum IPCE value of the $\mathrm{CdS} / \mathrm{Cu}_{\mathrm{x}} \mathrm{S}$ based solar cell $(65 \%)$ is higher than that of the CdS based device (50\%). IPCE value can be expressed as multiplication of LHE, $\eta_{\mathrm{cc}}$, and the charge injection efficiency $\left(\phi_{\text {inj }}\right)^{41}$
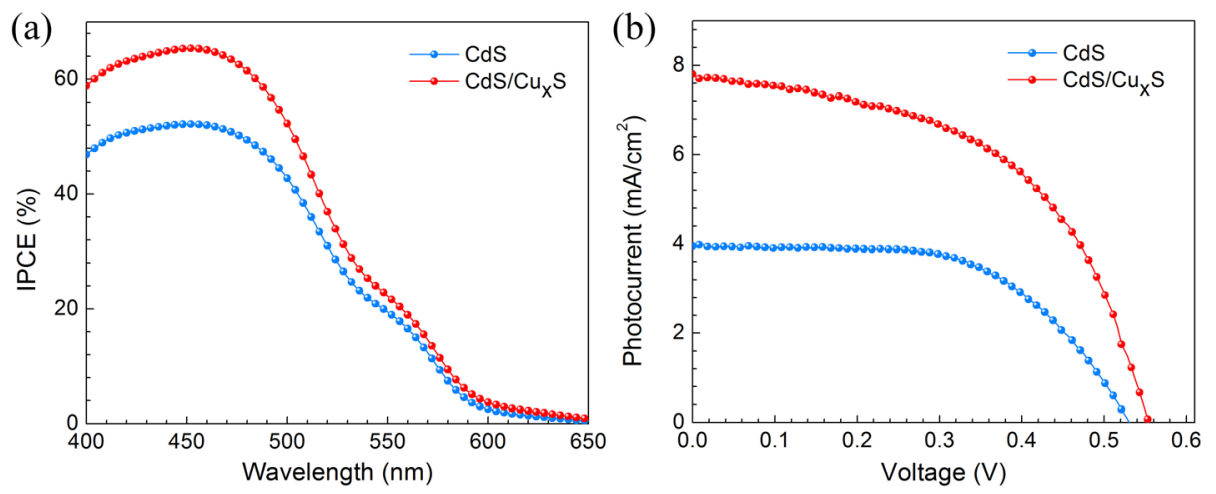

FIG. 3. (a) Incident photon to charge carrier efficiency (IPCE) curves and (b) $J-V$ curves of QDSCs with and without $\mathrm{Cu}_{\mathrm{x}} \mathrm{S}$ modification measured under $\mathrm{AM} 1.5 \mathrm{G}$, at 1 sun light intensity. 
TABLE I. Photovoltaic properties obtained from the $J-V$ curves. The standard deviation of the properties is based on the data of four cells in parallel.

\begin{tabular}{lcccc}
\hline \hline Samples & $V_{o c}(\mathrm{~V})$ & $J_{s c}\left(\mathrm{~mA} / \mathrm{cm}^{2}\right)$ & $\mathrm{FF}$ & $\eta(\%)$ \\
\hline $\mathrm{CdS}$ & 0.53 & 3.95 & 0.58 & $1.21 \pm 0.13$ \\
$\mathrm{CdS} / \mathrm{Cu}_{\mathrm{x}} \mathrm{S}$ & 0.56 & 8.53 & 0.59 & $2.78 \pm 0.22$ \\
\hline \hline
\end{tabular}

$$
I P C E=L H E \times \phi_{i n j} \times \eta_{c c} .
$$

It is clear that the enhanced LHE and $\eta_{\mathrm{cc}}$ by $\mathrm{Cu}_{\mathrm{x}} \mathrm{S}$ modification account for the improvement of IPCE in real device, while $\phi_{\text {inj }}$ is probably not affected.

Figure 3(b) shows the photocurrent density-voltage $(J-V)$ curves of the QDSCs under simulated solar illumination $\left(100 \mathrm{~mW} / \mathrm{cm}^{2}\right.$, AM $\left.1.5 \mathrm{G}\right)$. The photovoltaic properties of the devices are summarized in Table I. Under the illumination, the properties of $\mathrm{CdS} / \mathrm{Cu}_{\mathrm{x}} \mathrm{S}$ sensitized solar cells are $0.56 \mathrm{~V}$ of open-circuit voltage $\left(V_{o c}\right), 8.53 \mathrm{~mA} / \mathrm{cm}^{2}$ of short current density $\left(J_{s c}\right)$, and $59 \%$ of fill factor $(\mathrm{FF})$. All these photovoltaic parameters are improved compared to the neat $\mathrm{CdS}$ sensitized solar cell. The improvement of $J_{s c}$ is related to the IPCE spectrum, ${ }^{42,43}$ which is caused by the enhancement of light absorption and $\eta_{\mathrm{cc}}$. The increase of $V_{o c}{ }^{44}$ and $\mathrm{FF}^{45}$ is attributed to the reduced surface charge recombination and prolonged electron lifetime. As a result, the PCE of $\mathrm{CdS} / \mathrm{Cu}_{\mathrm{x}} \mathrm{S}$ based device is more than two times higher (from $1.21 \%$ to $2.78 \%$ ), compared with the CdS based device.

In summary, in situ cationic exchange method was introduced to prepare a $\mathrm{Cu}_{\mathrm{x}} \mathrm{S}$ layer on the surface of $\mathrm{CdS}$ QDs to improve the electron collection efficiency of QDSCs. The layer of $\mathrm{Cu}_{\mathrm{x}} \mathrm{S}$ is considered as hole transporter to boost the hole transfer from CdS QDs to electrolyte with corresponding reduction of the charge recombination and increase of the electron collection efficiency. In addition, $\mathrm{Cu}_{\mathrm{x}} \mathrm{S}$ has a narrower band-gap $(1.2 \mathrm{eV})$ that improves the light absorbance and extends the absorption range. As a result, both the electron collection efficiency and PCE of the solar cell are increased from $80 \%$ to $92 \%$ and from $1.21 \%$ to $2.78 \%$, respectively.

This work was supported by the National Science Foundation of China (51374029, 5151101345), Program for New Century Excellent Talents in University (NCET-130668), Fundamental Research Funds for the Central Universities (FRF-TP-14-008C1). T.P. and K.Z. were supported by the Swedish Research Council and KAW foundation.

${ }^{1}$ P. H. R. Vogel and H. Weller, J. Phys. Chem. 98, 3183-3188 (1994).

${ }^{2}$ M. R. Kim and D. Ma, J. Phys. Chem. Lett. 6, 85-89 (2015).

${ }^{3}$ L. H. Qu, W. W. Yu, W. Z. Guo, and X. G. Peng, Chem. Mater. 15, 2854-2860 (2003).

${ }^{4}$ W. A. Tisdale, K. J. Williams, B. A. Timp, D. J. Norris, E. S. Aydil, and X. Y. Zhu, Science 328, 1543-1547 (2010).

${ }^{5}$ A. J. Nozik, Chem. Phys. Lett. 457, 3-11 (2008).

${ }^{6}$ A. J. Nozik, Inorg. Chem. 44, 6893-6899 (2005).

${ }^{7}$ W. Shockley, J. Appl. Phys. 32, 1402-1404 (1961).

${ }^{8}$ H. Zhang, K. Cheng, Y. Hou, Z. Fang, Z. Pan, W. Wu, J. Hua, and X. Zhong, Chem. Commun. 48, 11235-11237 (2012).
${ }^{9}$ P. K. Santra and P. V. Kamat, J. Am. Chem. Soc. 134, 2508-2511 (2012).

${ }^{10}$ L.-H. Lai, M. J. Speirs, F.-K. Chang, L. Piveteau, J.-S. Chen, J.-J. Wu, and M. A. Loi, Appl. Phys. Lett. 107, 183901 (2015).

${ }^{11}$ K.-H. Lin, C.-Y. Chuang, Y.-Y. Lee, F.-C. Li, Y.-M. Chang, I. P. Liu, S.C. Chouand, and Y.-L. Lee, J. Phys. Chem. C 116, 1550-1555 (2012).

${ }^{12}$ D. Scheunemann, S. Wilken, J. Parisi, and H. Borchert, Appl. Phys. Lett. 103, 133902 (2013).

${ }^{13}$ J.-Y. Kim, J. Yang, J. H. Yu, W. Baek, C.-H. Lee, H. J. Son, T. Hyeon, and M. J. Ko, ACS Nano 9, 11286-11295 (2015).

${ }^{14}$ G. Wang, H. Wei, Y. Luo, H. Wu, D. Li, X. Zhong, and Q. Meng, J. Power Sources 302, 266-273 (2016).

${ }^{15}$ J. Yang, J. Wang, K. Zhao, T. Izuishi, Y. Li, Q. Shen, and X. Zhong, J. Phys. Chem. C 119, 28800-28808 (2015).

${ }^{16}$ V. Chakrapani, D. Baker, and P. V. Kamat, J. Am. Chem. Soc. 133, 9607-9615 (2011).

${ }^{17}$ Z. Yang, C.-Y. Chen, C.-W. Liu, C.-L. Li, and H.-T. Chang, Adv. Energy Mater. 1, 259-264 (2011).

${ }^{18}$ Q. Shen, A. Yamada, S. Tamura, and T. Toyoda, Appl. Phys. Lett. 97, 123107 (2010).

${ }^{19}$ K. Yan, L. Zhang, J. Qiu, Y. Qiu, Z. Zhu, J. Wang, and S. Yang, J. Am. Chem. Soc. 135, 9531-9539 (2013).

${ }^{20}$ J. Tian, L. Lv, C. Fei, Y. Wang, X. Liu, and G. Cao, J. Mater. Chem. A 2, 19653-19659 (2014).

${ }^{21}$ J. Huang, B. Xu, C. Yuan, H. Chen, J. Sun, L. Sun, and H. Agren, ACS Appl. Mater. Interfaces 6, 18808-18815 (2014).

${ }^{22}$ J. J. Tian and G. Z. Cao, J. Phys. Chem. Lett. 6, 1859-1869 (2015).

${ }^{23}$ M. A. Hines and P. Guyot-Sionnest, J. Phys. Chem. 100, 468-471 (1996).

${ }^{24}$ Q. Shen, J. Kobayashi, L. J. Diguna, and T. Toyoda, J. Appl. Phys. 108, 84304-84311 (2008).

${ }^{25}$ I. Mora-Sero, S. Gimenez, F. Fabregat-Santiago, R. Gomez, Q. Shen, T. Toyoda, and J. Bisquert, Acc. Chem. Res. 42, 1848-1857 (2009).

${ }^{26}$ Z. Pan, I. Mora-Sero, Q. Shen, H. Zhang, Y. Li, K. Zhao, J. Wang, X. Zhong, and J. Bisquert, J. Am. Chem. Soc. 136, 9203-9210 (2014).

${ }^{27}$ K. Zhao, Z. Pan, I. Mora-Seró, E. Cánovas, H. Wang, Y. Song, X. Gong, J. Wang, M. Bonn, J. Bisquert, and X. Zhong, J. Am. Chem. Soc. 137, 5602-5609 (2015).

${ }^{28}$ Z. Zhang, J. Yang, X. Wen, L. Yuan, S. Shrestha, J. A. Stride, G. J. Conibeer, R. J. Patterson, and S. Huang, J. Phys. Chem. C 119, 24149-24155 (2015).

${ }^{29}$ J. J. Li, Y. A. Wang, W. Z. Guo, J. C. Keay, T. D. Mishima, M. B. Johnson, and X. G. Peng, J. Am. Chem. Soc. 125, 12567-12575 (2003).

${ }^{30}$ See supplementary material at http://dx.doi.org/10.1063/1.4952435 for the details of materials, device fabrication and characterization.

${ }^{31}$ Y. Xu and M. A. A. Schoonen, Am. Mineral. 85, 543-556 (2000).

${ }^{32}$ J. Tian, Q. Feng, E. Uchaker, R. Gao, X. Qu, S. Zhang, and G. Cao, Energy Environ. Sci. 6, 3542-3547 (2013).

${ }^{33}$ J. G. Radich, N. R. Peeples, P. K. Santra, and P. V. Kamat, J. Phys. Chem. C 118, 16463-16471 (2014).

${ }^{34}$ J. Tian, Q. Zhang, L. Zhang, R. Gao, L. Shen, S. Zhang, X. Qu, and G. Cao, Nanoscale 5, 936-943 (2013).

${ }^{35}$ L. Lu, J. Chen, and W. Wang, Appl. Phys. Lett. 103, 2123902 (2013).

${ }^{36}$ P. V. Kamat, J. A. Christians, and J. G. Radich, Langmuir 30, 5716-5725 (2014).

${ }^{37}$ Z. Pan, H. Zhang, C. Kan, Y. Hou, J. Hua, and X. Zhong, ACS Nano 6, 3982-3991 (2012).

${ }^{38}$ S. Pang, Ke. Cheng, S. Xu, G. Cheng, and Z. Du, Appl. Phys. Lett. 104, 201601 (2014).

${ }^{39}$ T. Oekermann, D. Zhang, T. Yoshida, and H. Minoura, J. Phys. Chem. B 108, 2227-2235 (2004).

${ }^{40}$ Y. Wang, K. Li, Y. Xu, H. Rao, C. Su, and D. Kuang, Nanoscale 5, 5940-5948 (2013).

${ }^{41}$ S. S. Shin, J. S. Kim, J. H. Suk, K. D. Lee, D. W. Kim, J. H. Park, K. S. Hong, I. S. Cho, and J. Y. Kim, ACS Nano 7, 1027-1035 (2013).

${ }^{42}$ J. Yang, T. Oshima, W. Yindeesuk, Z. Pan, X. Zhong, and Q. Shen, J. Mater. Chem. A 2, 20882-20888 (2014).

${ }^{43}$ S.-C. Lin, Y. Lee, C.-H. Chang, Y.-J. Shen, and Y.-M. Yang, Appl. Phys. Lett. 90, 143517 (2007).

${ }^{44}$ D. Esparza, I. Zarazúa, T. López-Luke, R. Carriles, A. Torres-Castro, and E. D. I. Rosa, Electrochim. Acta 180, 486-492 (2015).

${ }^{45}$ X. Zhang, Y. Justo, J. Maes, W. Walravens, J. Zhang, J. Liu, Z. Hens, and E. M. J. Johansson, J. Mater. Chem. A 3, 20579-20585 (2015). 